\title{
Optimal energy management strategies to reduce diesel consumption for a hybrid off-grid system
}

\author{
Gestión de energía óptima para reducir el consumo de diesel en un sistema híbrido aislado
}

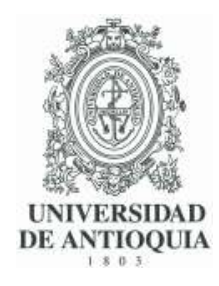

\author{
Paul Arévalo-Cordero $\mathbb{B}^{1,2}$, Darío J. Benavides $\mathbb{1}^{1,2}$, Juan Leonardo Espinoza $\mathbb{B}^{2}$, Luis Hernández-Callejo $\mathbb{B}^{3 *}$, \\ Francisco Jurado (iD 1 \\ ${ }^{1}$ Departamento de Ingeniería Eléctrica, Universidad de Jaén. Campus Las Lagunillas, s/n. C. P. 23071. Jaén, España. \\ ${ }^{2}$ Facultad de Ingeniería - DEET, Universidad de Cuenca. Avenida 12 de Abril. C. P. 010107. Cuenca, Ecuador. \\ ${ }^{3}$ Departamento Ingeniería Agrícola y Forestal, Universidad de Valladolid. Campus Universitario Duques de Soria. C. P. 42004. Soria, \\ España.
}

\section{CITE THIS ARTICLE AS: \\ P. Arévalo, D. J. Benavides, J. \\ L. Espinosa, L. Hernández and \\ F. Jurado. "Optimal energy \\ management strategies to \\ reduce diesel consumption for a hybrid off-grid system", \\ Revista Facultad de Ingeniería \\ Universidad de Antioquia, no. \\ 98, pp. 47-58, Jan-Mar 2021. \\ [Online]. Available: https: \\ //www.doi.org/10.17533/ \\ udea.redin. 20200471}

\section{ARTICLE INFO:}

Received: November 12, 2019 Accepted: April 15, 2020

Available online: April 15, 2020

\section{KEYWORDS:}

Microgrid; energy storage; renewable energy

Microrred; almacenamiento de energía; energía renovable
ABSTRACT: Although climate change is a reality, many off-grid communities continue to use diesel generators for electricity supply. This document presents a strategy to reduce diesel consumption in an out-of-grid system formed by renewable sources (PV-HKT-WT-DG). Three energy dispatch strategies have been proposed to verify the impact on diesel consumption and generator operating hours. In addition, different energy storage technologies lacid lead, lithium-ion, vanadium redox flow, pump storage and supercapacitorl have been considered. The HOMER software has been used to calculate the optimal size of the systems through technical-economic indicators. The results show that it is possible to reduce diesel consumption progressively; however, the cost of energy increases. On the other hand, when using lithium-ion batteries under charge cycle control, the penetration of the diesel generator has been greatly reduced without affecting the cost of the system. Finally, sensitivity analyzes have shown that when demand increases, diesel consumption does not increase significantly by using redox vanadium flow batteries, whereas the diesel generator operating hours decrease significantly in all systems.

RESUMEN: Aunque el cambio climático es una realidad, muchas comunidades fuera de la red continúan utilizando generadores diesel para suministrar electricidad. Por lo tanto, este documento presenta una estrategia para reducir el consumo de diesel en un sistema fuera de la red formado por fuentes renovables (PV-HKT-WT-DG). Se han propuesto tres estrategias de despacho de energía para verificar el impacto en el consumo de diesel y las horas de operación del generador. Además, se han considerado diferentes tecnologías de almacenamiento de energía (plomo ácido, iones de litio, flujo redox de vanadio, almacenamiento de bomba y supercondensador). El software HOMER se ha utilizado para calcular el tamaño óptimo de los sistemas a través de indicadores técnico-económicos. Los resultados muestran que es posible reducir el consumo de diesel progresivamente, sin embargo el costo de la energía aumenta. Por otro lado, al usar las baterías de ion litio bajo el control ciclo de carga, la penetración del generador diesel se ha reducido considerablemente sin afectar al costo del sistema. Finalmente, los análisis de sensibilidad han demostrado que: al incrementarse la demanda, el consumo de diesel no incrementa significativamente al usar baterías de flujo de vanadio redox y las horas de operacion del generador diesel disminuyen considerablemente en todos los sistemas.

\section{Introduction}

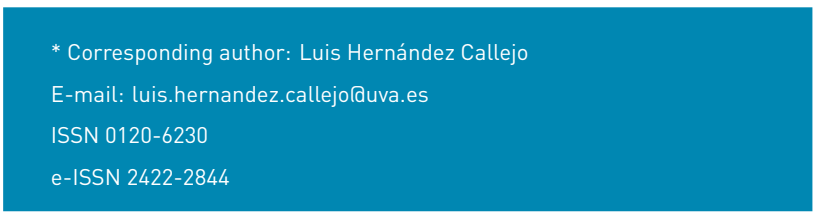

Sustainable development considerations are essential for a society in constant economic growth. Therefore, future generations must consume energy through clean technologies without compromising the environment. 
Energy sources such as solar photovoltaic panels (PV) and wind turbines (WT) have been frequently used, due to their constant cost reductions and growing industrial and residential applications. Several studies related to the mentioned technologies have been analyzed in cases of isolated communities powered by off-grid hybrid systems that use both technologies simultaneously, backed by a diesel generator [1]. The conclusions have shown that, when using more than one renewable source, the system energy efficiency is greater and the operation of the diesel generator (DG) is significantly reduced. On the other hand, hydrokinetic energy (HKT) is currently a promising technology considering the economic advantage of its installation. This study analyzes an off-grid hybrid system formed by PV-WT-HKT-DG to reduce the operation and fuel consumption of diesel generators. There are several computational methods to evaluate the behavior of renewable systems, depending on the environmental conditions of the study site [2-9]. References [10-19] explain the analysis of the performance and sizing optimization in renewable hybrid systems composed of photovoltaic (PV) and wind energy (WT). Some studies use computational tools such as HOMER and Matlab to find an optimal model through objective functions. In addition, several works use various methods to reduce $\mathrm{CO}_{2}$ emissions, for example, energy control systems to start the diesel generator depending on the state of renewable sources and batteries. Therefore, different energy storage technologies have been considered to analyze the impact on the renewable hybrid system [20].

An interesting source of renewable power generation is hydrokinetic turbines (HKT). This is an innovative technology as it does not need dikes to generate electricity. Similarly, systems composed of hydrokinetic turbines have been analyzed with promising results. One of the great advantages of this system is the ease of installation. Being a turbine taking advantage of the speed of the fluid, it is possible to install it directly in a river or canal. References [21, 22] present studies related to photovoltaic - hydrokinetic off-grid systems, by usinglead-acid batteries and hydrogen tanks as energy storage. The results show that the hydrogen system implies a higher investment cost, but over time it turns out to be cheaper than a lead-acid system. In general, these studies show that the system can meet the demand without technical problems, minimizing the operation of the diesel generator. Further, some studies have reported the possibility of using the turbine flow for storage by pumping plants. The sizing of the energy storage system should be optimal, in case of oversizing the system the cost would be too high and the project would not be economically profitable. On the other hand, if diesel fuel were subsidized then the diesel generator would have to provide more energy-producing more $\mathrm{CO}_{2}$ emissions. Both the type of Energy Storage System(ESS) and the energy control strategy significantly influence the results.In the case of the pump storage system, the increase in demand should also be considered as well as the combination with other renewable technologies that could be complementary [23-30].

In reference [20], various types of batteries have been investigated, of which lead-acid (LAB) batteries have been used the most. However, Lithium-Ion (Li-ion) batteries are being used more frequently, since they have a life expectancy and energy density higher than $L A B$, and the production price of these batteries has decreased considerably in recent years. Therefore, $\mathrm{Li}$-ion technology is considered a competitive option. [31-34]. Another of the technologies that are booming is the Vanadium Redox Flow (VRF) technology. VRF is a type of rechargeable battery that uses vanadium ions in different oxidation states to store chemical potential. Their life expectancy can reach 20 years. Additionally, it has an optimal response to high load variations. Furthermore, ESS is composed of supercapacitors, to soften the power peaks produced by a system, and storage by pumping for large-scale loads are relatively new applications. Several studies demonstrate their advantages when applied to renewable systems [35-44].

The importance of analyzing the effects of energy control on a system composed of renewable energy sources (HKT-WT-PV) is evident as the combination of these technologies in an isolated system has not yet been fully developed in the literature. This article presents three types of energy dispatch: Cycle charging (CC), Load following (LF) and combined cycle (CD). The objective of this study is to reduce the operation of the back-up diesel generator in a system consisting of renewable sources (HKT-WT-PV) using various energy storage technologies such as: lead-acid, lithium-ion, redox vanadium flow, pump storage, and supercapacitor. The originality of this article lies in the impact that each ESS technology causes on the system and the reduction of diesel generator operation and diesel consumption. For this, a sensitivity analysis regarding the increase in demand in each case and the selected control strategy is performed. To obtain concrete results, the following indicators have been studied: Net present cost (NPC), Cost of energy (COE) and $\mathrm{CO}_{2}$ emissions. The system has been modeled and simulated in the Homer pro computational tool through idealized models. Finally, this article is an extension of the document published at the ICSC-CITIES 2019 conference, entitled "Impact on a microgrid using different storage systems under three energy dispatch control" [45]. 


\section{Methodology}

Several types of variables have been used to perform the proposed analysis. The main input variables are radiation, wind speed, river speed and demand, all for one year. The output variables are indicators that allow evaluating the response of the system to various situations that may arise; these are NPC, $\mathrm{COE}$ and $\mathrm{CO}_{2}$ emissions. The outputs have been analyzed for each type of ESS proposed in the study. Section 2.1 presents a background study, in which the daily and seasonal demand curves are indicated. Section 2.2 shows the annual renewable resources present in the area of study. The mathematical representation of each system component is developed in section 2.3. In section 2.4, the objective function approach for each type of proposed energy control has been carried out, as well as the parameters of the system components. In section 2.5, the results of the simulation are presented including the sensitivity analysis performed. Finally, section 3 discusses the conclusions of the study.

\subsection{Background}

The case under study is a public University located in southern Ecuador. The average daily power demand curve is shown in Figure 1. It is evident that, the peak demand appears at night from 18:00 h until 21:00 h and the minimum demand occurs in the early hours of the morning that corresponds mainly to lighting and video surveillance systems.

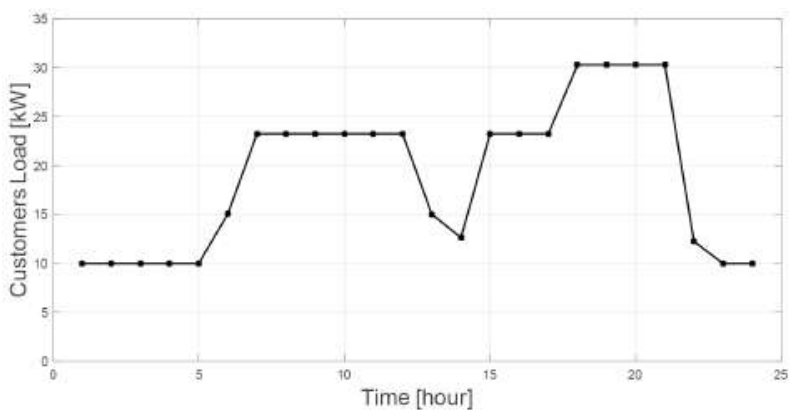

Figure 1 Electric demand daily [kW]

With respect to seasonal demand, the first three months of the year have considerable variations, in other months the demand maintains the same trend. In Figure 2, the seasonal demand taken from the electric meters located in the university is indicated. In addition, a zoom has been made to show in detail the first days of the year.

\subsection{Renewable resources}

Renewable resources such as solar radiation have been taken from a weather station located at the study site. In Figure 3 , the average daily radiation is presented for one
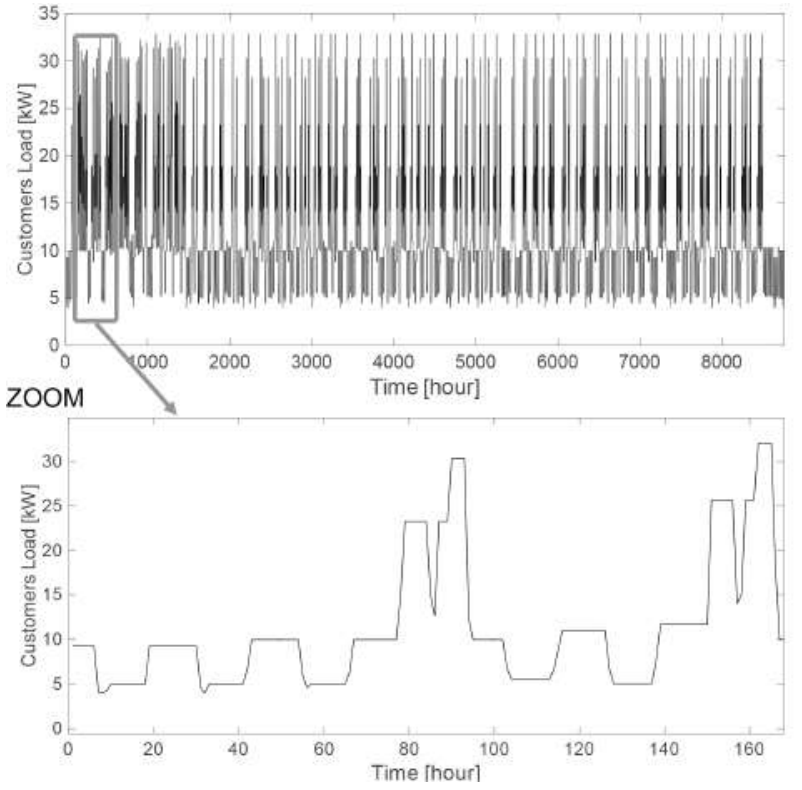

Figure 2 Seasonal demand [kW]

year, the first 160 days are indicated in detail, it is observed that throughout the year there have been no considerable variations. Likewise, the average wind speed has been

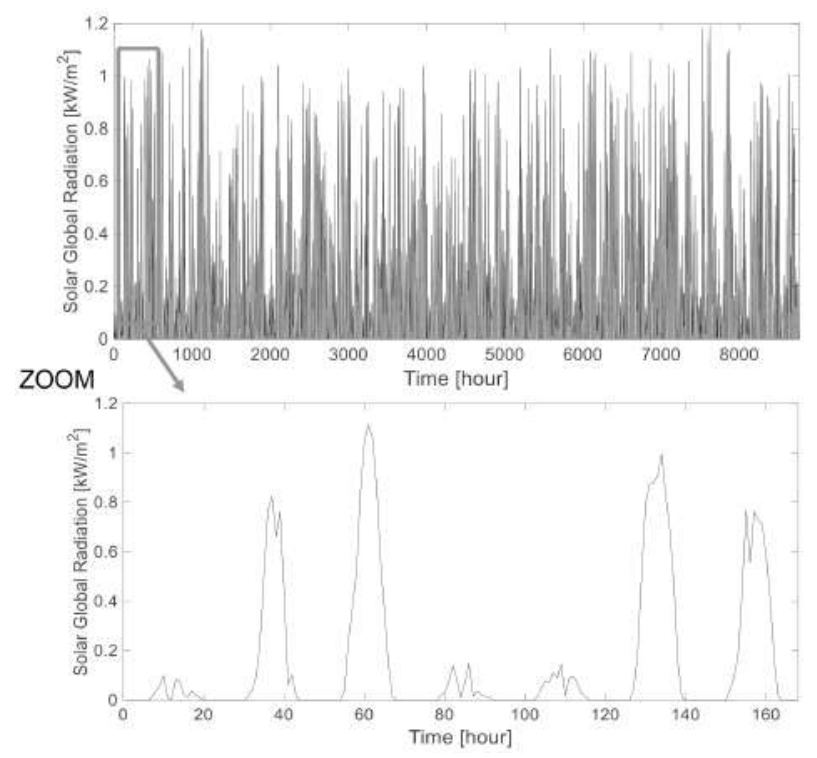

Figure 3 Global solar radiation $\left[k W / m^{2}\right]$

obtained for one year. In Figure 4, the variation of this resource is indicated. It is evident that the resource is greater during June to September. However, for November to February, the resource decreases. The water resource has been obtained using flow control measurements in a hydrological station installed at the study site, average river speeds have been achieved for one year. The river speed during a year and a detail of the first 160 days are shown in Figure 5 . It can be observed that, for June until 


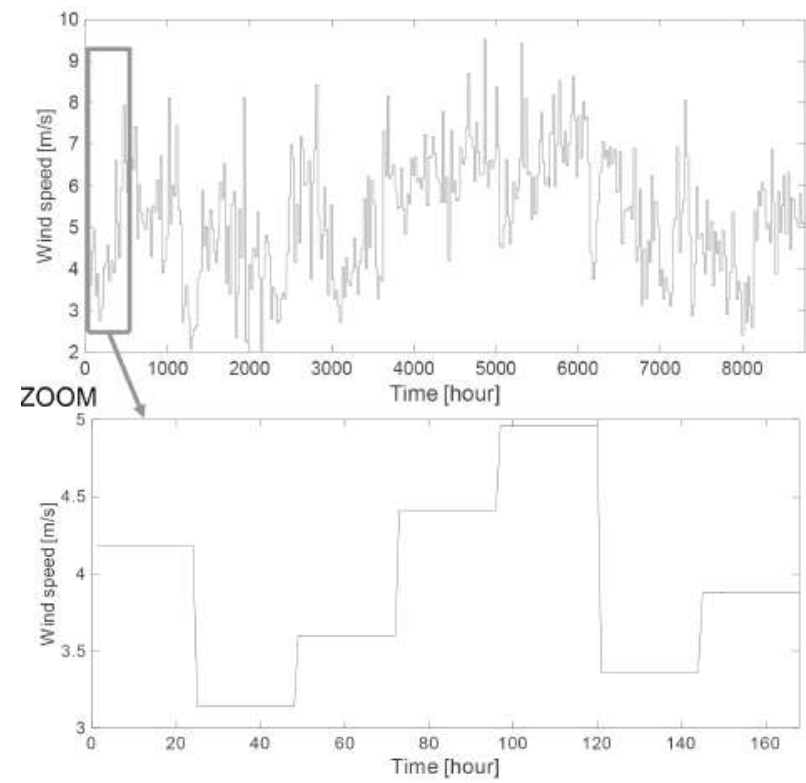

Figure 4 Wind speed in $[\mathrm{m} / \mathrm{s}]$

September, the water resource is lower compared to the other months of the year. Therefore, it is favorable for the system since the resource is complementary concerning the wind speed.

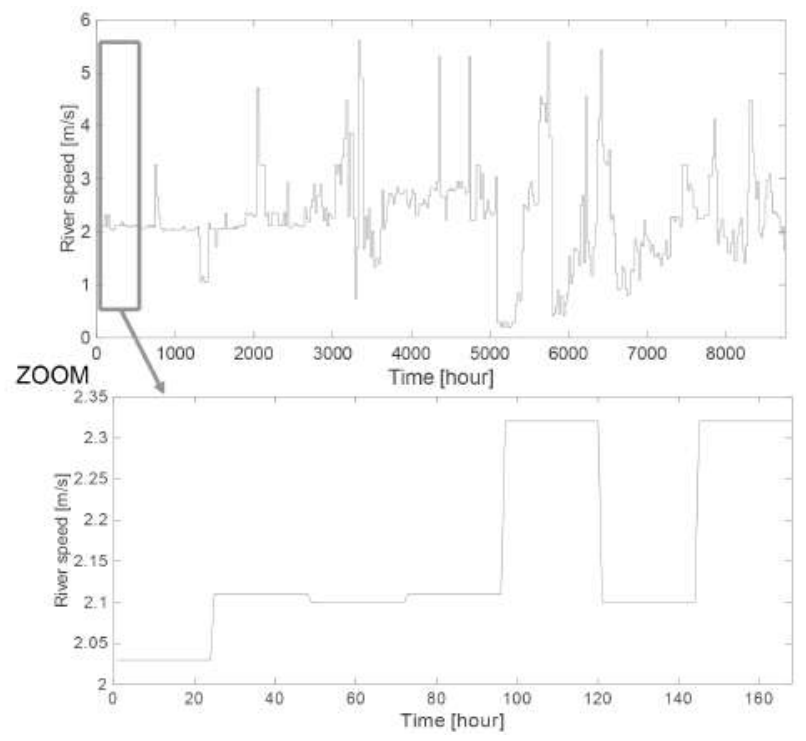

Figure 5 River speed in $[\mathrm{m} / \mathrm{s}]$

\subsection{Mathematical representation}

The scheme in HOMER using the proposed renewable sources is shown in Figure 6. The mathematical representations used by the software are shown below.

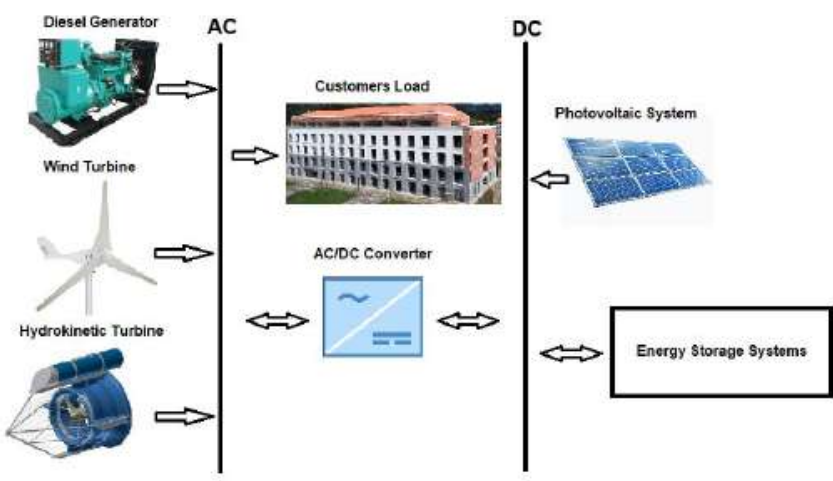

Figure 6 Proposed hybrid system

Photovoltaic system

The output power of a photovoltaic system depends on the weather conditions at the installation site, Equation (1) is a simplified model of the output power [5].

$$
P_{P V}=P_{S T C} *\left(\frac{G_{H R}}{G_{S T C}}\right) *\left[1+k\left(T_{c}-T_{a}\right)\right]
$$

Where:

$P_{P V}: \quad$ Photovoltaic output power [kW]

$G_{H R}: \quad$ Incident irradiation $\left[k W / m^{2}\right]$

$k: \quad$ Temperature coefficient $\left[-0.37 \% /{ }^{\circ} \mathrm{C}\right]$

$G_{S T C}$ : Incident irradiation in standard condition $\left[k W / m^{2}\right]$

$T_{C}$ : $\quad$ Cell temperature in standard conditions $\left[{ }^{\circ} \mathrm{C}\right]$

$T_{a}: \quad$ incident temperature $\left[25^{\circ} \mathrm{C}\right]$

\section{Hydrokinetic turbine}

The power produced by a hydrokinetic turbine depends directly on the speed of the river, the sweeping area of its blades and the efficiency of the turbine and the engine. It is similar to the wind turbine, but the density of water is approximately 800 times higher than the air. The power of the hydrokinetic turbine is given by Equation (2) [21-23].

$$
P_{H K T}=\left(\frac{1}{2}\right) * \rho w * A * v^{3} * C_{p, H} * \eta_{H K T}
$$

Where: $P_{H K T}$ is the power of the hydrokinetic turbine (HKT), $(\rho w)$ is the water density in $\mathrm{kg} / \mathrm{m}^{3}$, HKT performance coefficient $\left(C_{p, H}\right)$, combined HKT-generator efficiency $\left(\eta_{H K T}\right)$, HKT area (A) in $m^{2}$, water flow velocity $(v)$ in $\mathrm{m} / \mathrm{s}$ and time $(t)$ in seconds. 


\section{Wind furbine}

Countless equations represent a wind turbine. However, the objective is to present an equation that represents the main variables of the system, since the objective of the article does not focus on the exact modeling of each component but the energy flow as a whole. Reference [10] presents the power of the wind turbine (Equation (3)).

$$
P_{W T}=\eta_{r e c} *\left(\frac{1}{2}\right) * C_{p \max } * \rho * \Pi * R^{2} * v^{3}
$$

Where: $P_{W T}$ is the output power of the wind turbine, $\eta_{r e c}$, is the efficiency of the controller $(95 \%)$, in this case, the maximum MPPT power monitoring is included, $\rho$ is the air density, $R$ is the radius of the rotor, $C_{p \max }$ is the power coefficient and $v$ the wind speed $[10,46]$.

\section{Diesel generator}

The proposed diesel generator is a conventional generator set that, in off-grid systems, supports energy deficit. Equation (4) represents the energy output of the DG [23].

$$
E_{D G}=P_{D G} * \eta_{D G} * t
$$

Where: $P_{D G}$ is the nominal power of $\mathrm{DG}, \eta_{D G}$ is the efficiency of the DG and $t$ is the time. To consider the price of fuel, several parameters such as transportation and subsidies must be taken into account

\section{Batteries}

For each time step, HOMER calculates the maximum amount of energy that the battery bank can absorb (LAB, li-ion, VRF). The controller uses this maximum load power when making decisions depending on the type of energy control used, as if the storage bank can absorb all available excess renewable energy. The maximum load power varies from a one-time step to another depending on its charging status and its recent loading and unloading history. Equation (5) provides the maximum amount of energy that can be absorbed by the system $[47,48]$.

$P_{b}(t)=\frac{k * Q_{1}(t) * e^{-k * \Delta t}+Q(t) * k * c *\left(1-e^{-k * \Delta t}\right)}{1-e^{-k * \Delta t}+c *\left(k * \Delta t-1+e^{-k * \Delta t}\right)}$

Where: $Q_{1}(t)$ is the energy available at the beginning of the operating interval in the minimum SOC. In the case of LAB this value is $40 \%$, in Li-lon batteries, it is $20 \%$ and for VRF is $0 \%$, the maximum SOC for the three systems will be $100 \%$ considering idealized models. $Q(t)$ Is the total energy at the beginning of the passage of time, $c$ is the ratio of the storage capacity of each system, $k$ is the constant energy storage rate, and $\Delta t$ is the time interval [47]. Supercapacitor The supercapacitor is based on the idealized storage model that assumes a flat discharge curve because the supply voltage remains constant during the discharge cycle. For this model, it is only needed to enter the nominal capacity in ampere-hours. HOMER uses this as the actual storage capacity. Energy stored (joules) in a supercapacitor can be calculated using the Equation (6) [47]:

$$
E=\left(\frac{1}{2}\right) * C * V^{2}
$$

Where: $E$ is the energy stored in joules, $C$ is the capacitance in farads, and $V$ is the voltage in volts [49].

\section{Pumped storage hydropower}

It has been considered storage by pumping (PH), which consists of a motor and a reservoir, the energy storage capacity of a pumped hydroelectric system is calculated using Equation (7) [43, 47]:

$$
E=9.81 * \rho_{w} * V_{\text {res }} * h_{\text {head }} * \eta
$$

Where:

$E: \quad$ Is the energy stored in joules.

$\rho_{w}$ : Is the density of water usually about $1000 \mathrm{~kg} / \mathrm{m}^{3}$.

$V_{\text {res }}: \quad$ Is the volume of the reservoir in cubic meters, in this case $1000 \mathrm{~m} 3$

$h_{\text {head }}$ Is the head height in meters, in this study $100 \mathrm{~m}$.

$\eta: \quad$ Is the efficiency of the energy conversion, and must consider losses like turbine efficiency, generator efficiency, and hydrodynamic losses, usually $90 \%$ [47].

\section{Converter DC/AC}

The inverter must be a two-way energy flow converter, to connect the modules and batteries in DC to the load and generation WT/HKT in AC, the output power is shown in Equation (8) [20, 33, 37, 48].

$$
P_{O}(t)=P_{i}(t)=* \eta_{i n v}
$$

Where: $P_{0}(t)$ is the power output of the inverter, $P_{i}(t)$ is the input power of the inverter and $\eta_{i n v}$ is the efficiency of the inverter, in this case, $96 \%$.

\subsection{Energy control strategies}

This section defines the types of energy flow control to minimize the penetration of the diesel generator. Table 1 shows the parameters used in each component for the simulation, the values have been obtained from HOMER as this tool presents updated reference prices. 
Table 1 Components of a hybrid system

\begin{tabular}{ccccccccccc} 
Parameters & LAB & SC & VRF & PH & AC/DC & HKT & Li-lon & DG & PV & WT \\
\hline Rated power & $1 \mathrm{kWh}$ & $20 \mathrm{kWh}$ & $100 \mathrm{kWh}$ & $245 \mathrm{kWh}$ & $10 \mathrm{~kW}$ & $5 \mathrm{~kW}$ & $1 \mathrm{kWh}$ & $37 \mathrm{~kW}$ & $0.3 \mathrm{~kW}$ & $10 \mathrm{~kW}$ \\
\hline $\begin{array}{c}\text { Capital cost } \\
\text { (\$/kW) }\end{array}$ & 250 & $180 \$ / 300 \mathrm{~F}$ & 5500 & $\begin{array}{c}28000 \\
\$ / 245 \mathrm{kWh}\end{array}$ & 320 & 11600 & 410 & 470 & 1350 & 4900 \\
\hline $\mathbf{0 \& M} \mathbf{\$} / \mathbf{y r})$ & 14 & 40 & 150 & 200 & 10 & 40 & 20 & $0.05 \$ / \mathrm{h}$ & 12 & 23 \\
\hline $\begin{array}{c}\text { Lifeexpectancy } \\
\text { (yr) }\end{array}$ & 8 & 25 & 20 & 50 & 12 & 18 & 12 & $15,000 \mathrm{~h}$ & 25 & 22 \\
\hline
\end{tabular}

\section{Dispatch strategy cycle charging}

Total renewable energy $\left(E_{R E}\right)$ is composed of: hydrokinetic energy $\left(E_{H K T}\right)+$ wind energy $\left(E_{W T}\right)+$ photovoltaic energy $\left(E_{P V}\right)$ and is shown in Equation (9).

$$
E_{R E}=E_{H K T}+E_{W T}+E_{P V}
$$

In ideal conditions of the renewable system, renewable energy is capable of supplying demand $\left(E_{L O A D}\right)$ and recharging the energy storage system, Equation (10) represents the ideal conditions $\left(E_{S S}\right)$.

$$
E_{R E}=E_{L O A D}+E_{E S S}
$$

If renewable energy is not enough to supply the demand, the energy storage system must assume that deficit as long as they are recharged above their minimum state of charge, this is indicated by Equation (11).

$$
E_{L O A D}=E_{R E}+E_{E S S}
$$

If conditions persist and renewable energy has not been recovered, the ESS is discharged to the minimum SOC. In that case, the diesel generator must be started at full load to exclusively recharge the ESS until reaching a SOC of $80 \%$. Therefore, the objective function is as follows in Equation (12) [48].

$$
E_{L O A D}=\begin{gathered}
E_{R E}+\left(E_{D G \max }-E_{S S}\right), I f \rightarrow R E \prec \text { Load;and,If } \\
\rightarrow S O C \leq S O C \min \\
E_{R E}+E_{S S}, I f \rightarrow R E \prec L \text { Lad;and } I f \\
\rightarrow S O C \succ 80 \%
\end{gathered}
$$

\section{Dispatch load following strategy}

Like the previous case, total renewable energy $\left(E_{R E}\right)$ is composed of: hydrokinetic energy $\left(E_{H K T}\right)+$ wind energy $\left(E_{W T}\right)+$ photovoltaic energy $\left(E_{P V}\right)$.

In ideal conditions of the renewable system, renewable energy is capable of supplying demand $\left(E_{L O A D}\right)$ and recharging the energy storage system $\left(E_{S S}\right)$.

If renewable energy is not enough to supply the demand, the energy storage system must assume that deficit as long as they are recharged above their minimum state of charge.
However, if the ESS charge status is less than $S O C_{\min }$, the diesel generator $\left(E_{D G}\right)$ must be started. But not to recharge the batteries as in the previous case, but to supply the demand as required until renewable sources can supply the demand again. In this case, the batteries are recharged with an excess of renewable energy, as indicated in Equation (13).

$$
E_{L O A D}=E_{R E}+E_{D G}
$$

Therefore, the objective function is presented in Equation (14) [48]:

$$
E_{L O A D}=\begin{gathered}
E_{R E}+E_{D G}, I f \rightarrow R E \prec \text { Load;and,If } \rightarrow S O C \leq S O C \text { min } \\
E_{R E}-E_{S S}, I f \rightarrow R E \succ \text { Load;and,I } \rightarrow S O C \prec 80 \% \\
E_{R E}, I f \rightarrow R E \succ \text { Load;and,I } \rightarrow S O C \succ 80 \%
\end{gathered}
$$

\section{Combined cycle dispatch strategy}

The decision of the controller depends on the cost of energy. Related to the system conditions, the controller must choose between the cycle charging and load-following controls. The combined dispatch strategy uses the net load $\left(E_{L O A D}-E_{R E}\right)$ to make a decision. The controller must use the cycle charging strategy if the current net load is low, approximately less than $20 \%$ of the total load power $\left(E_{T}\right)$. On the other hand, if the current net load is high the controller must choose the load following strategy. HOMER optimizes each of the options to meet the demand by comparing the cost of charging the battery (with the diesel generator) to the cost of charging the battery using excess renewable energy for each time interval. Therefore, the objective function is as follows, Equation (15) [50].

$E_{L O A D}=\begin{aligned} & \text { CycleChargingControl } ; \text { I } \rightarrow\left(E_{\text {Load }}-E_{R E}\right) \prec 0.2 * E_{T} \\ & \text { LoadFollowingControl } ; \text { If } \rightarrow\left(E_{\text {Load }}-E_{R E}\right) \geq 0.2 * E_{T}\end{aligned}$

\subsection{Results and comments}

The simulation has been carried out using HOMER software. In each case the optimal sizing values are calculated, they serve as a comparison between the different energy storage systems proposed. The controls used in this article present novel results. For example, in the case of the LF control, the NPC is lower in the case 
of lead-acid batteries, lithium-ion, pumping storage and vanadium redox flow. In the case of the supercapacitor, the values remain similar for both the $\mathrm{CC}$ control and LF. On the other hand, the CD control presents different results than the other controls, in most systems the result of the NPC and COE are greater for this type of control. The results of the NPC are shown in Figure 7 and the results of the COE are presented in Figure 8, the COE has the same tendency as the NPC. In summary, the lowest NPC corresponds to the supercapacitor under cycle charging control whereas the lowest COE is for the pumped hydroelectricity under LF control. The

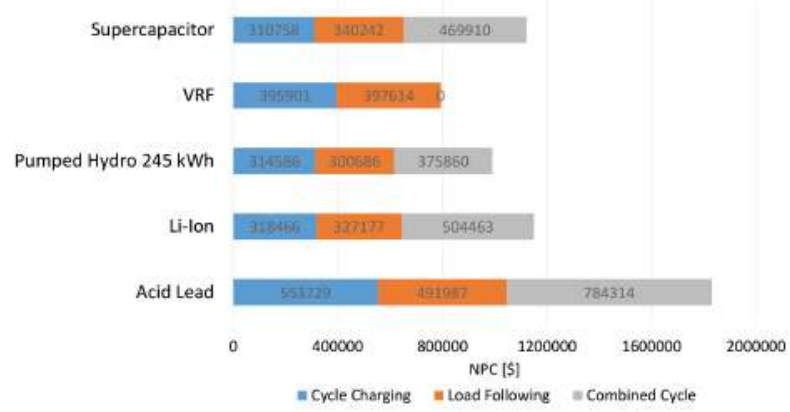

Figure $\mathbf{7}$ Net present cost in each system

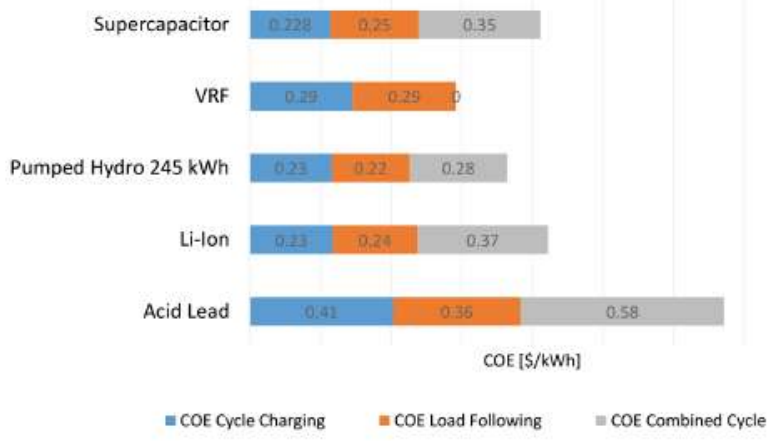

Figure 8 Cost of energy in each system

results of $\mathrm{CO}_{2}$ emissions reflect the operation of the diesel generator because it is the only element that produces these emissions. Using the energy dispatch cycle charging, the systems that provide the most $\mathrm{CO}_{2}$ are: VRF and SC, followed by pump storage, Li-lon and the least polluting are LABs. However, when using the load following energy dispatch, pump storage has shown the lowest level of $\mathrm{CO}_{2}$ emissions followed by Li-lon and VRF batteries. It is worth mentioning that for the vanadium flow system it is not profitable to apply the combined control. Similarly, using the combined cycle it can be seen that the emissions produced by lead-acid batteries have decreased considerably and the emissions in pump storage have increased, the other systems still have high
$\mathrm{CO}_{2}$ emissions. These results are the product of the ESS type, its response time to load peaks and the state of charge of each system. The results are shown in Figure 9. The system with the lowest $\mathrm{CO}_{2}$ emissions is pumped hydro under load following control. Table 2 shows the size

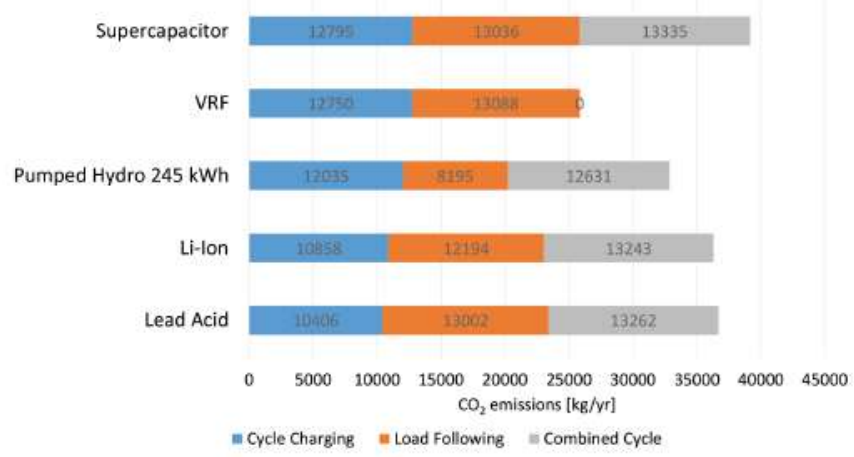

Figure $9 \mathrm{CO}_{2}$ emissions

optimization for the proposed systems. The result of the DG is the same for all systems (37 kW) except for VRF under $C D$ control, since it is not economically viable. Regarding diesel consumption, lead-acid batteries under CD control have obtained a favorable result. However, to achieve this, the number of solar panels had to be increased to $20 \mathrm{~kW}$ and the number of WT to 86 raising the NPC to $\$ 784,000$. On the other hand, lithium-ion batteries show a different result, under the $\mathrm{CC}$ control the lowest penetration of the DG has been obtained with $470 \mathrm{~h} / \mathrm{yr}$ of operation and consumption of $4000 \mathrm{l} / \mathrm{yr}$. Moreover, the NPC is relatively lower $(\$ 319,000)$ and it has been recommended not to use solar panels, therefore it has been used 10 WT and $10 \mathrm{HKT}$.

The VRF and the SC present greater penetration values of the DG both with optimal values under the CC control. However, the system with the lowest NPC penetration is the storage by pumping with NPC $=\$ 300,000$; even though the DG penetration is still high with $644 \mathrm{~h} / \mathrm{yr}$ and fuel consumption of $3,100 \mathrm{l} / \mathrm{yr}$ under the LF control. Therefore, the recommended system is Li-ion under CC control.

\section{Sensitivity analysis}

The objective of the sensitivity analysis is to verify the impact of the increased demand on the penetration of the diesel generator, using the different ESS proposed. Figure 10 shows the result of the sensitivity analysis under the CC control. It is obvious that, increasing demand also increases fuel consumption. However, the increase is different for each ESS. It can be noted that, the storage by pumping has the largest slope followed by the SC and LAB alternative; lithium batteries have a smaller slope. On the other hand, VRF presents an approximately constant behavior, being the one with the least sensitivity to the demand increase. The different behavior is due to the 
Table 2 Optimization results

\begin{tabular}{|c|c|c|c|c|c|c|c|c|c|c|c|c|c|c|c|}
\hline \multirow[t]{2}{*}{ Parameters } & \multicolumn{3}{|c|}{ Lead Acid } & \multicolumn{3}{|c|}{ Li-Ion } & \multicolumn{3}{|c|}{ PH } & \multicolumn{3}{|c|}{ VRF } & \multicolumn{3}{|c|}{ SC } \\
\hline & $\mathrm{CC}$ & LF & $\mathrm{CD}$ & $\mathrm{CC}$ & LF & $C D$ & $\mathrm{CC}$ & LF & CD & $\mathrm{CC}$ & LF & $C D$ & $\mathrm{CC}$ & LF & $\mathrm{CD}$ \\
\hline NPC (\$)X1000 & 554 & 492 & 784 & 319 & 327 & 505 & 315 & 300 & 376 & 396 & 398 & 0 & 311 & 340 & 470 \\
\hline DG (kW) & 37 & 37 & 37 & 37 & 37 & 37 & 37 & 37 & 37 & 37 & 37 & 0 & 37 & 37 & 37 \\
\hline $\begin{array}{l}\text { Fuel consumption } \\
(\mathrm{l} / \mathrm{yr}) \times 1000\end{array}$ & 3.9 & 4.9 & 2.2 & 4 & 4.7 & 5.1 & 4.6 & 3.1 & 4.9 & 4.9 & 5 & 0 & 4.9 & 5 & 5.1 \\
\hline $\begin{array}{l}\text { DG operation } \\
\text { (h/yr) }\end{array}$ & 422 & 950 & 354 & 470 & 937 & 691 & 570 & 644 & 539 & 930 & 1,000 & 0 & 565 & 990 & 576 \\
\hline PV (kW) & 10 & 10 & 20 & 0 & 0 & 40 & 2 & 0 & 60 & 0 & 4 & 0 & 0 & 4 & 60 \\
\hline WT \# & 15 & 14 & 86 & 10 & 13 & 31 & 8 & 11 & 18 & 13 & 13 & 0 & 9 & 22 & 39 \\
\hline HKT \# & 5 & 5 & 1 & 10 & 8 & 0 & 8 & 8 & 0 & 10 & 8 & 0 & 10 & 5 & 0 \\
\hline
\end{tabular}

type of batteries and their energy and power density. In addition to increasing demand, excess energy from renewable sources is used in the analysis.

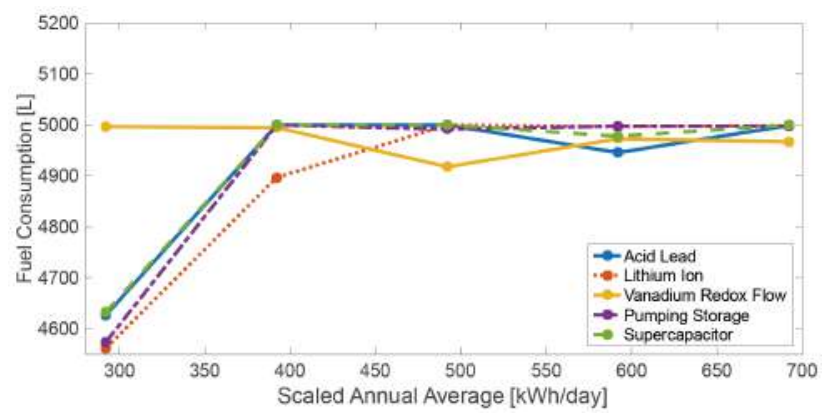

Figure 10 Fuel consumption under CC control

In the case of the LF control, the trend is similar to the previous case with a difference in the pump storage system, which presents larger variations. The DG must start at full power but for a shorter time interval. On the other hand, under the control LF the DG starts with less power but more time. The sensitivity analysis under the LF control is shown in Figure 11. Under the CD control,

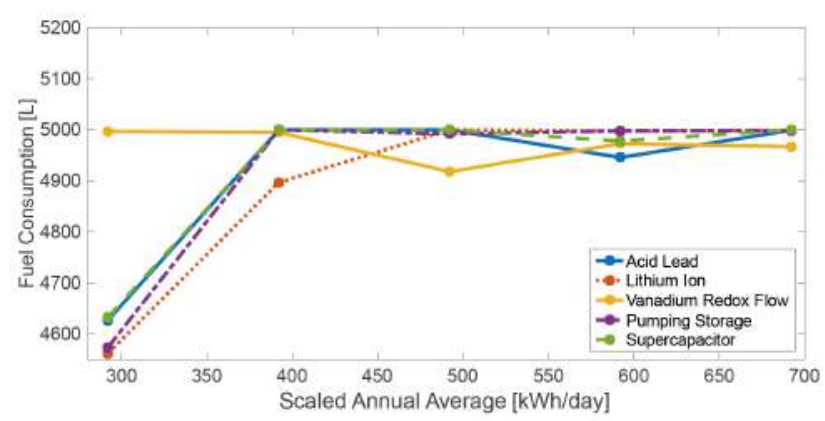

Figure 11 Fuel consumption under LF control

a more constant behavior is observed in Figure 12, the increase in fuel consumption is the same at the beginning of the demand growth and the end. This is the result of the combination of the CC and LF controls. Again, the pump storage system is the one that has presented the highest sensitivity to the increase in demand and the $\mathrm{SC}$ is the one that has remained almost constant. In

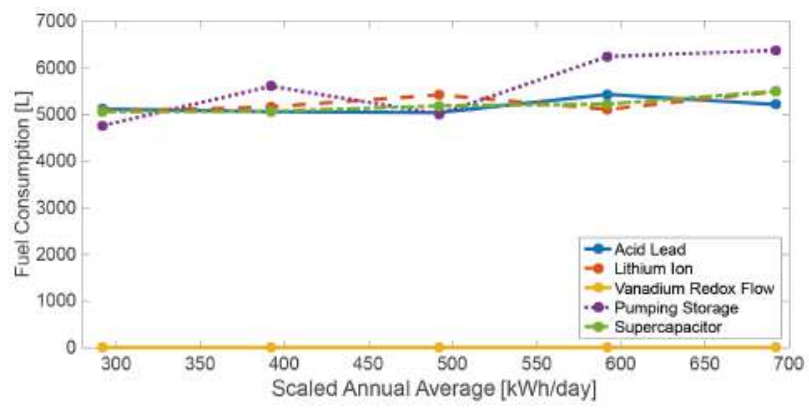

Figure 12 Fuel consumption under CD control

the autonomous system, while the electricity demand grows, the diesel generator's operating hours decrease, except for the SC under CC control. Figure 13 shows the behavior of the diesel generator against the increase in demand. The reason for this behavior is that, it is cheaper to generate more renewable energy or increase energy storage than to operate the diesel generator. Therefore, VRF, Li-ion, LAB present a decrease in the hours of operation of the DG, while the storage by pumping at the beginning has an increase to finally decrease to the same starting point. On the other hand, SC needs the DG to operate more hours to supply the demand. As for the

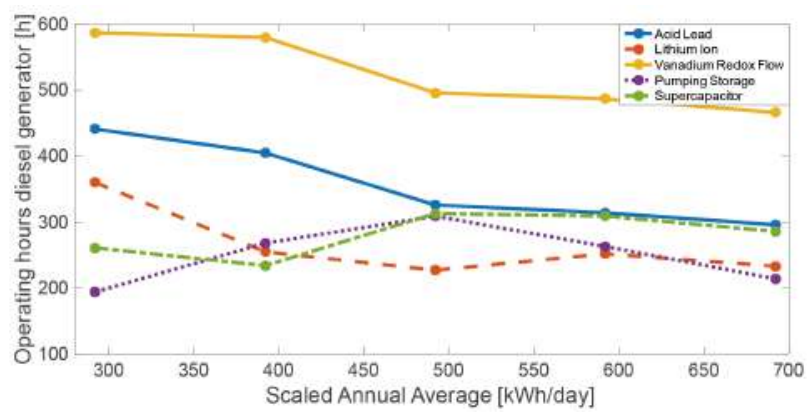

Figure 13 DG operating under CC control 


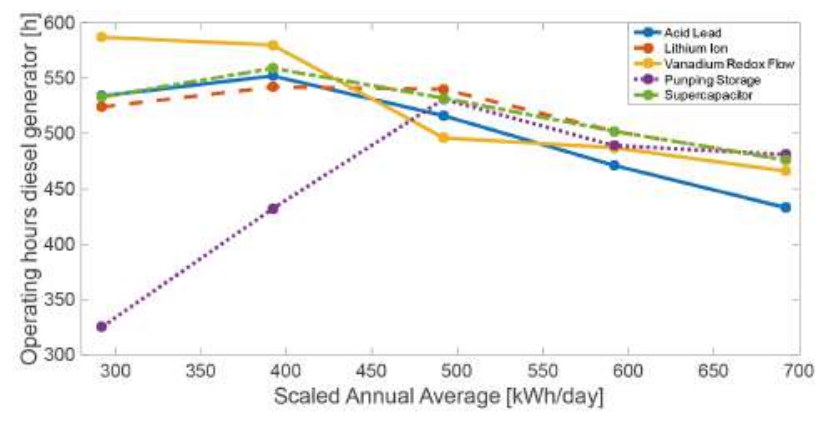

Figure 14 DG operating under LF control

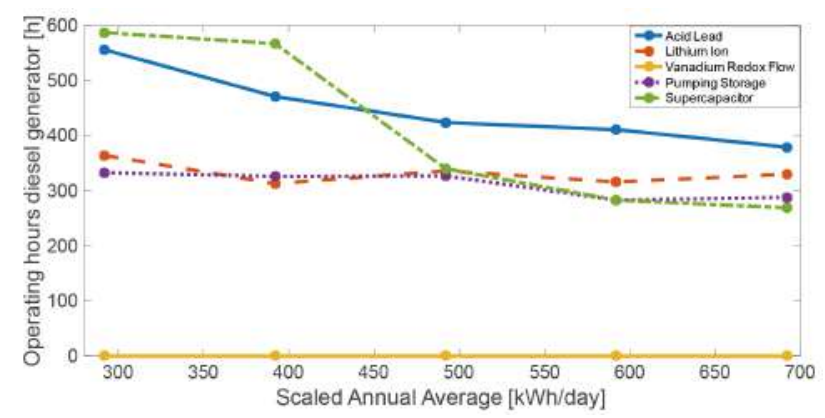

Figure $15 \mathrm{DG}$ operating under $\mathrm{CD}$ control

LF control (see Figure 14), the hours of operation of the diesel generator decrease while increasing the demand for several proposed storage systems. However, at the beginning of the increase in demand, there is an increase in the operating hours of the diesel generator. Due to the type of pump storage technology, at the beginning, it has presented a considerable increase to finally decrease to a greater point than the initial one. In this type of control, the DG starts with the power required by the load, so it can operate less time at higher power. Finally, the technology that has presented the greatest variation is LAB.

The result of the analysis under the $C D$ control is observed in Figure 15. It is well known that the hours of operation of the diesel generator always decrease while the demand increases, in this case, the system that has shown the greatest variation is the $\mathrm{SC}$ followed by $\mathrm{LAB}$.

The results obtained are novel, since it has been demonstrated the possibility of supplying the demand through the proposed hybrid system. Also, it has been possible to reduce the penetration of the diesel generator using energy control techniques by observing the impact on different energy storage systems.

The output power of the diesel generator is shown in Figure 16. Lithium-lon technology is taken as an example. It is observed that for the CC control the generator always starts at full load, in LF control it starts as required demand and the $C D$ control is a combination of the $C C$ and
LF controls. It is important to mention that under the load cycle control the penetration of the DG is lower.
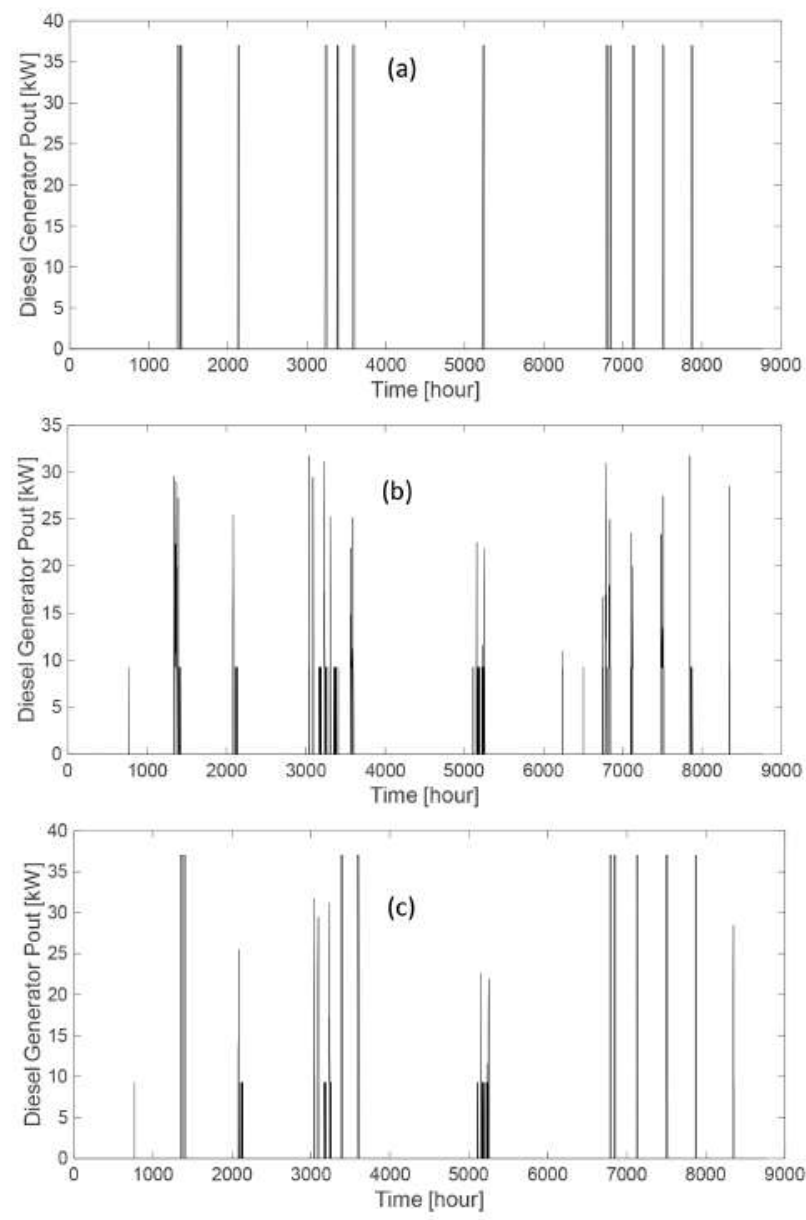

Figure 16 DG Power output: (a) Cycle charging, (b) Load following, (c) Combined dispatch

\section{Conclusions}

In this work, a strategy for reducing diesel consumption has been carried out for a hybrid off-grid system (PV-HKT-WT-DG). The strategy defines the optimal sizing of the system and minimizes the fuel consumption of a diesel generator, using three different energy dispatch controls (CC, LF, and $C D$ ) and energy storage systems ( $L A B, L i-i o n, V R F$, Pumped storage, and SC). When starting the diesel generator to directly recharge the energy storage system with CC controllusing, Li-ion, VRF and $\mathrm{SC}$ ) it has been proven that the diesel generator consumes less fuel and operates fewer hours per year as compared to the LF and CD controls.

In the case of the lead-acid storage system, it is possible to further reduce fuel consumption (2200 l/yr) and DG 
operating hours (354 h) by increasing the installed power of PV to $20 \mathrm{~kW}, \mathrm{WT}$ to 86 units. However, in this case, the NPC is not profitable $(\$ 784,000)$. The most favorable system is the one made up of lithium-ion batteries under $\mathrm{CC}$ control, which has presented a diesel consumption of $4000 \mathrm{l} / \mathrm{yr}$ and $470 \mathrm{~h} / \mathrm{yr}$ of DG operation. In this case, the optimal sizing does not include PV technology and the cost of the system is fair.

In addition, the sensibility analysisof scaled annual average [kWh/day] vs diesel consumption [L] has shown that while the demand increases, diesel consumption under the CC and LF controls increases in two phases, the first part exponentially and finally linearly. In the case of the CD control, it is always linear. In some higher demand values, diesel consumption decreases and this behavior is due to the possibility of using excess energy from renewable sources with their random resources and the type of ESS, because each storage system has different technical characteristics such as its power and energy densities.

Finally, the sensibility study of scaled annual average [kWh] vs operating hours diesel generator [h] has shown novel results, since while the demand increases, the hours of operation of the diesel generator are reduced, due to the cost of fuel with respect to the cost of renewable sources. When calculating the optimal configuration, renewable sources are always prioritized, thus $\mathrm{CO}_{2}$ emissions will also be reduced. The acid lead storage systemhas shown a greater reduction of DG penetration under $\mathrm{CC}$ and $\mathrm{LF}$ control, followed by VRF, Li-ion. On the other hand, the storage of pumping and SC present an increase of DG penetration at the beginning and decreases at the end of interval.

In the CD control, SC always shows a decrease of DG penetration and is the most prominent, followed by acid lead, li-ion and pumping storage.

To gather the information that allows the study to be evaluated more precisely, it is advisable to analyze more variables for verifying the impact of the evolution of certain system indicators such as SOCmin, time step, etc. In addition, it would be of great interest to analyze the same system on the grid. These studies will be carried out in future work.

\section{Declaration of competing interest}

None declared under financial, profesional and personal competing interests.

\section{Acknowledgements}

The authors thank the CYTED Thematic Network "CIUDADES INTELIGENTES TOTALMENTE INTEGRALES, EFICIENTES Y SOSTENIBLES (CITIES)" No 518RT0558. Financed by "Programa Iberoamericano de Ciencia y Tecnología para el Desarrollo" - CYTED.

\section{References}

[1] I. Hadjipaschalis, A. Poullikkas, and V. Efthimiou, "Overview of current and future energy storage technologies for electric power applications," Renewable and Sustainable Energy Reviews, vol. 13, no. 6-7, August 2009. [Online]. Available: https://doi.org/10.1016/j. rser.2008.09.028

[2] F. K. Abo and A. Elnozahy, "Bi-objective economic feasibility of hybrid micro-grid systems with multiple fuel options for islanded areas in Egypt," Renew. Energy, vol. 128, December 2018. [Online]. Available: https://doi.org/10.1016/j.renene.2018.05.066

[3] H. J. Vermaak, K. Kusakana, and S. P. Koko, "Status of micro-hydrokinetic river technology in rural applications: A review of literature," Renew. Sustain. Energy Rev., vol. 29, January 2014. [Online]. Available: https://doi.org/10.1016/j.rser.2013.08.066

[4] M. Castañeda, A. Cano, F. Jurado, H. Sánchez, and L. M. Fernández, "Sizing optimization, dynamic modeling and energy management strategies of a stand-alone PV/hydrogen/battery-based hybrid system," Int. J. Hydrogen Energy, vol. 38, no. 10, April 12013. [Online]. Available: https://doi.org/10.1016/j.ijhydene.2013.01.080

[5] 0. Djelailia, M. S. Kelaiaia, H. Labar, S. Necaibia, and F. Merad, "Energy hybridization photovoltaic/diesel generator/pump storage hydroelectric management based on online optimal fuel consumption per kWh," Sustain. Cities Soc., vol. 44, January 2019. [Online]. Available: https://doi.org/10.1016/j.scs.2018.09.037

[6] L. Olatomiwa, S. Mekhilef, M. S. Ismail, and M. Moghavvemi, "Energy management strategies in hybrid renewable energy systems: A review," Renew. Sustain. Energy Rev., vol. 62, September 2016. [Online]. Available: https://doi.org/10.1016/j.rser.2016.05.040

[7] R. Siddaiah and R. P. Saini, "A review on planning, configurations, modeling and optimization techniques of hybrid renewable energy systems for off grid applications," Renew. Sustain. Energy Rev., vol. 58, May 2016. [Online]. Available: https://doi.org/10.1016/j.rser. 2015.12.281

[8] A. H. Fathima and K. Palanisamy, "Optimization in microgrids with hybrid energy systems - A review," Renew. Sustain. Energy Rev., vol. 45, May 2015. [Online]. Available: https://doi.org/10.1016/j.rser. 2015.01.059

[9] S. Bahramara, M. P. Moghaddam, and M. R. Haghifam, "Optimal planning of hybrid renewable energy systems using HOMER: A review," Renew. Sustain. Energy Rev., vol. 62, September 2016. [Online]. Available: https://doi.org/10.1016/j.rser.2016.05.039

[10] M. Belouda, M. Hajjaji, H. Sliti, and A. Mami, "Bi-objective optimization of a standalone hybrid PV-Wind-battery system generation in a remote area in Tunisia," Sustain. Energy, Grids Networks, vol. 16, December 2018. [Online]. Available: https: //doi.org/10.1016/j.segan.2018.09.005

[11] K. Anoune, M. Bouya, A. Astito, and A. Ben, "Sizing methods and optimization techniques for pv-wind based hybrid renewable energy system: A review," Renew. Sustain. Energy Rev., vol. 93, October 2018. [Online]. Available: https://doi.org/10.1016/j.rser.2018.05.032

[12] M. J. Khan, A. K. Yadav, and L. Mathew, "Techno economic feasibility analysis of different combinations of PV-Wind-Diesel-Battery hybrid system for telecommunication applications in different cities of Punjab, India," Renew. Sustain. Energy Rev., vol. 76, September 2017. [Online]. Available: https://doi.org/10.1016/j.rser.2017.03.076

[13] V. Indragandhi, V. Subramaniyaswamy, and R. Logesh, "Resources, configurations, and soft computing techniques for power 
management and control of PV/wind hybrid system," Renew. Sustain. Energy Rev., vol. 69, March 2017. [Online]. Available: https://doi.org/10.1016/j.rser.2016.11.209

[14] A. S. Al, H. A. Kazem, A. H. Al-Badi, and M. Farooq, "A review of optimum sizing of hybrid PV-Wind renewable energy systems in oman," Renew. Sustain. Energy Rev., vol. 53, January 2016. [Online]. Available: https://doi.org/10.1016/j.rser.2015.08.039

[15] A. Haghighat, S. A. Avella, B. Najafi, A. Shirazi, and F. Rinaldi, "Techno-economic feasibility of photovoltaic, wind, diesel and hybrid electrification systems for off-grid rural electrification in Colombia," Renew. Energy, vol. 97, November 2016. [Online]. Available: https://doi.org/10.1016/j.renene.2016.05.086

[16] A. Maleki, M. Ameri, and F. Keynia, "Scrutiny of multifarious particle swarm optimization for finding the optimal size of a PV/wind/battery hybrid system," Renew. Energy, vol. 80, August 2015. [Online]. Available: https://doi.org/10.1016/j.renene.2015.02.045

[17] S. Sinha and S. S. Chandel, "Review of recent trends in optimization techniques for solar photovoltaic-wind based hybrid energy systems," Renewable and Sustainable Energy Reviews, vol. 50, October 2015. [Online]. Available: https: //doi.org/10.1016/j.rser.2015.05.040

[18] A. Mahesh and K. S. Sandhu, "Hybrid wind/photovoltaic energy system developments: Critical review and findings," Renew. Sustain. Energy Rev., vol. 52, December 2015. [Online]. Available: https://doi.org/10.1016/j.rser.2015.08.008

[19] V. Khare, S. Nema, and P. Baredar, "Solar-wind hybrid renewable energy system: A review," Renew. Sustain. Energy Rev., vol. 58, May 2016. [Online]. Available: https://doi.org/10.1016/j.rser.2015.12.223

[20] A. Kaabeche and Y. Bakelli, "Renewable hybrid system size optimization considering various electrochemical energy storage technologies," Energy Convers. Manag., vol. 193, August 2019. [Online]. Available: https://doi.org/10.1016/j.enconman.2019.04.064

[21] J. Lata, F. Jurado, L. M. Fernández, and H. Sánchez, "Optimal hydrokinetic turbine location and techno-economic analysis of a hybrid system based on photovoltaic/hydrokinetic/hydrogen/battery," Energy, vol. 159, September 15 2018. [Online]. Available: https://doi.org/10.1016/ j.energy.2018.06.183

[22] J. Lata, F. Jurado, H. Sanchez, C. Reyes, and L. Fernandez, “Optimal sizing hydrokinetic-photovoltaic system for electricity generation in a protected wildlife area of Ecuador," Turkish J. Electr. Eng. Comput. Sci., vol. 26, no. 2, March 2018. [Online]. Available: https://doi.org/10.3906/elk-1706-23

[23] K. Kusakana, "Optimization of the daily operation of a hydrokinetic-diesel hybrid system with pumped hydro storage," Energy Convers. Manag., vol. 106, December 2015. [Online]. Available: https://doi.org/10.1016/j.enconman.2015.10.021

[24] K. Kusakana, "Energy management of a grid-connected hydrokinetic system under Time of Use tariff," Renew. Energy, vol. 101, February 2017. [Online]. Available: https://doi.org/10.1016/j.renene.2016.10. 019

[25] K. Kusakana and H. J. Vermaak, "Cost and performance evaluation of hydrokinetic-diesel hybrid systems," Energy Procedia, vol. 61, 2014. [Online]. Available: https://doi.org/10.1016/j.egypro.2014.12. 019

[26] K. Kusakana, "Techno-economic analysis of off-grid hydrokinetic-based hybrid energy systems for onshore/remote area in South Africa," Energy, vol. 68, April 15 2014. [Online]. Available: https://doi.org/10.1016/j.energy.2014.01.100

[27] S. P. Koko, K. Kusakana, and H. J. Vermaak, "Optimal power dispatch of a grid-interactive micro-hydrokinetic-pumped hydro storage system," J. Energy Storage, vol. 17, June 2018. [Online]. Available: https://doi.org/10.1016/j.est.2018.02.013

[28] K. Kusakana and H. J. Vermaak, "Hydrokinetic power generation for rural electricity supply: Case of South Africa," Renew. Energy, vol. 55, July 2013. [Online]. Available: https://doi.org/10.1016/j. renene.2012.12.051

[29] D. Kumar and S. Sarkar, "A review on the technology, performance, design optimization, reliability, techno-economics and environmental impacts of hydrokinetic energy conversion systems," Renew. Sustain. Energy Rev., vol. 58, May 2016. [Online]. Available: https://doi.org/10.1016/j.rser.2015.12.247

[30] K. Kusakana, "Feasibility analysis of river off-grid hydrokinetic systems with pumped hydro storage in rural applications," Energy Convers. Manag., vol. 96, May 15 2015. [Online]. Available: https: //doi.org/10.1016/j.enconman.2015.02.089

[31] A. Parasuraman, T. M. Lim, C. Menictas, and M. Skyllas, "Review of material research and development for vanadium redox flow battery applications," Electrochim. Acta, vol. 101, July 2013. [Online]. Available: https://doi.org/10.1016/j.electacta.2012.09.067

[32] P. Alotto, M. Guarnieri, and F. Moro, "Redox flow batteries for the storage of renewable energy: A review," Renew. Sustain. Energy Rev., vol. 29, January 2014. [Online]. Available: https: //doi.org/10.1016/j.rser.2013.08.001

[33] B. K. Das, Y. M. Al-Abdeli, and M. Woolridge, "Effects of battery technology and load scalability on stand-alone PV/ICE hybrid micro-grid system performance," Energy, vol. 168, February 12019. [Online]. Available: https://doi.org/10.1016/j.energy.2018.11.033

[34] B. Zakeri and S. Syri, "Electrical energy storage systems: A comparative life cycle cost analysis," Renew. Sustain. Energy Rev., vol. 42, February 2015. [Online]. Available: https://doi.org/10.1016/ j.rser.2014.10.011

[35] A. Abdelkader, A. Rabeh, D. M. Ali, and J. Mohamed, "Multi-objective genetic algorithm based sizing optimization of a stand-alone wind/PV power supply system with enhanced battery/supercapacitor hybrid energy storage," Energy, vol. 163, November 152018. [Online]. Available: https://doi.org/10.1016/j.energy.2018.08.135

[36] L. W. Chong, Y. W. Wong, R. K. Rajkumar, and D. Isa, “An adaptive learning control strategy for standalone pv system with battery-supercapacitor hybrid energy storage system," J. Power Sources, vol. 394, August 1 2018. [Online]. Available: https: //doi.org/10.1016/j.jpowsour.2018.05.041

[37] L. Kong, J. Yu, and G. Cai, "Modeling, control and simulation of a photovoltaic/hydrogen/ supercapacitor hybrid power generation system for grid-connected applications," Int. J. Hydrogen Energy, vol. 44, no. 46, September 27 2019. [Online]. Available: https: //doi.org/10.1016/j.ijhydene.2019.05.097

[38] L. W. Chong, Y. W. Wong, R. K. Rajkumar, and D. Isa, "An optimal control strategy for standalone PV system with battery-supercapacitor hybrid energy storage system," J. Power Sources, vol. 331, November 1 2016. [Online]. Available: https://doi.org/10.1016/j.jpowsour.2016.09.061

[39] K. Sun, K. J. Li, J. Pan, and Y. Liu, "An optimal combined operation scheme for pumped storage and hybrid wind-photovoltaic complementary power generation system," Appl. Energy, vol. 242, May 2019. [Online]. Available: https://doi.org/10.1016/j.apenergy. 2019.03.171

[40] M. Miao, Z. Wu, S. Lou, and Y. Wang, "Research on optimizing operation of hybrid PV power and pumped hydro storage system," Energy Procedia, vol. 118, August 2017. [Online]. Available: https: //doi.org/10.1016/j.egypro.2017.07.023

[41] A. Rathore and N. P. Patidar, "Reliability assessment using probabilistic modelling of pumped storage hydro plant with PV-wind based standalone microgrid," Int. J. Electr. Power Energy Syst., vol. 106, March 2019. [Online]. Available: https://doi.org/10.1016/j. ijepes.2018.09.030

[42] G. Notton, D. Mistrushi, L. Stoyanov, and P. Berberi, “Operation of a photovoltaic-wind plant with a hydro pumping-storage for electricity peak-shaving in an island context," Sol. Energy, vol. 157, November 2017. [Online]. Available: https://doi.org/10.1016/j.solener.2017.08. 016

[43] B. Xu, D. Chen, M. Venkateshkumar, Y. Xiao, and Y. Xing, "Modeling a pumped storage power integration to a hybrid power system with solar-wind power and its stability analysis," Energy Procedia, vol. 158, February 2019. [Online]. Available: https://doi.org/10.1016/j.egypro.2019.01.475

[44] C. L. Chen, H. C. Chen, and J. Y. Lee, “Application of a generic superstructure-based formulation to the design of wind-pumped-storage hybrid systems on remote islands," Energy Convers. Manag., vol. 111, March 1 2016. [Online]. Available: 
https://doi.org/10.1016/j.enconman.2015.12.057

[45] W. P. Arévalo, D. J. Benavides, J. L. Espinoza, F.Jurado, and L. Hernández, "Impact on a microgrid using different storage systems under three energy dispatch control," in I/ Ibero-American Congress of Smart Cities (ICSCCITIES 2019), Soria, Spain, 2019, pp. $1-16$.

[46] S. Siniscalchi, F. D. Bianchi, M. de Prada, and C. Ocampo, "A wind farm control strategy for power reserve maximization," Renew. Energy, vol. 131, February 2019. [Online]. Available: https: //doi.org/10.1016/j.renene.2018.06.112

[47] Homer calculations. Homer Energy. Accessed Feb. 08, 2019. [Online]. Available: https://bit.ly/3aYBHfe

[48] P. Arévalo, D. Benavides, J. Lata, and F. Jurado, “Energy control and size optimization of a hybrid system (photovoltaic-hidrokinetic) using various storage technologies," Sustain. Cities Soc., vol. 52, January 2020. [Online]. Available: https://doi.org/10.1016/j.scs. 2019.101773

[49] D. N. Luta and A. K. Raji, "Optimal sizing of hybrid fuel cell-supercapacitor storage system for off-grid renewable applications," Energy, vol. 166, January 2019. [Online]. Available: https://doi.org/10.1016/j.energy.2018.10.070

[50] B. K. Das and F. Zaman, "Performance analysis of a PV/Diesel hybrid system for a remote area in bangladesh: Effects of dispatch strategies, batteries, and generator selection," Energy, vol. 169, February 15 2019. [Online]. Available: https://doi.org/10.1016/j. energy.2018.12.014 